\title{
Quality Evaluation and Sugar Beet Postharvest Conservation under Modified Atmosphere
}

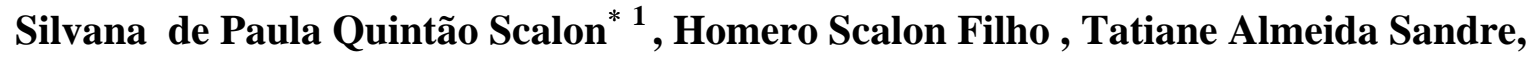 \\ Eulene Francisco da Silva and Eliane Caetano Domingos Krewer . \\ Universidade Federal do Mato Grosso do Sul, Departament of Agrarian Sciences, P.O. Box 533., Dourados - MS, \\ Brazil
}

\begin{abstract}
S
This work had as objective the evaluation of sugar beets postharvest conservation under modified atmosphere and at environmental temperature $\left(15-26^{\circ} \mathrm{C}\right)$. The experiment was entirely guided at a randomized design with three factorial sizes (small,, medium and large) and two packings (PVC and without packing) in three repetitions of five beets. They were appraised in the beginning and at the end of storage, for pH;Total Soluble Solids (TSS) and Total Titration Acidity (TTA) contents. During the storage, the percentage of weight loss percentage was also appraised. It was observed that the packing reduced between in eight to ninefold the weight loss, and the small beets presented smaller weight loss than the large ones. After 14 days they were stored, the beets without packing were useless for trade due to withered advanced phase, with medium weight loss of 55\%. The beets packed with PVC stayed with good appearance for 22 days of storage with medium loss weight of 15,82\%. The pH, TSS and TTA contents didn't present significant difference in packed beets, but at the $22^{\text {nd }}$ day TTA was larger in small beets. On the average, pH was larger while TTA and TSS were smaller for large beets.
\end{abstract}

Key words: Beta vulgaris, postharvest, modified atmosphere

\section{INTRODUCTION}

The beet (Beta vulgaris L. Chenopodiaceae family) is a vegetable which has a relatively an easy cultivation, and also presents a great economical importance, for its high nutritive and industrial value (Moura \& Siqueira, 1983). It is used as an alternative source for production of alcohol and forage of good nutritious value. It appears as a rotation program in winter culture, making possible the occupation of inactive areas in this period, increasing the agricultural income of the producer (Cerreta et al. , 1983).

The sugar beet is very nutritive and is frequently used in human nutrition. It is rich in proteins, vitamin $\mathrm{A}, \mathrm{B}_{1}, \mathrm{~B}_{2}$, C. Calcium, phosphorus and iron with concentrations of $14,38,0,8 \mathrm{mg} / 100 \mathrm{~g}$ (FEPLAM, 1973) respectively

Araújo et al. (1983) stand out the importance of the culture as being a plant among the vegetables with a considerable value for the extraction and utilization of natural dyes, betacyanina.

Roots, tubercules, bulbs and rhizomes are important constituents in a nutritional diet, representing about $70 \%$ of the total production of food (Coursey, 1986). The increase of food availability has been a great world concern due to populational growth and postharvest losses of horticultural products (fruits and vegetables), that some times reach $45 \%$ (Lopes, 1980).

Breathing is the main activity of the fruits and vegetables after harvest because they use their own reservations. This causes the loss of dry substance which propitiate the weight loss of the product and also affects their appearance, texture and nutritious quality (Kader, 1985). The utilization of modified atmosphere in fruits and vegetables conservation especially for the carrot, arracacha and beet is an efficient experience (Diatchenko, 1971; Phan, 1974; Avelar Filho, 1989; Scalon et al., 1998; Terrassioli Neto et al., 1998).

In reviews by Avelar Filho (1989), it was observed that the increase of $\mathrm{CO}_{2}$ concentration during the storage, reduces the carrots sprout, while the increase of $\mathrm{O}_{2}$ increases this sprout. It has been noticed that sprout stimulation could be one of the

\footnotetext{
* Author for correspondence
} 
possible damages caused from modified atmosphere in root vegetable roots (Kader, 1992).

For most of the fruits, water content is between 80-95\%,; therefore the water loss will result in weight losses, increasing the maturation and a consequent senescence. These water losses may be reduced maintaining the temperature and removing the heat of fruits respiration (vital heat), reduction of air stream and packing them in polyethylene bags (Pantastico et al. , 1975; Bleinroth, 1986).

The weight loss of carrots vary in different conditions of temperature and relative humidity. After 24 hours at $55 \% \mathrm{UR}$ and $25{ }^{\circ} \mathrm{C}$ the loss is $6,19 \%$ compared with $85 \%$ UR at $0,4{ }^{\circ} \mathrm{C}$ with loss of $0,11 \%$ (Apeland and Bangerod, 1971). The beet presents a medium storage life of higher than 12 weeks under temperatures lower than $10^{\circ} \mathrm{C}$ (Wills, 1981). Tsunechiro et al. (1994) noticed the losses of beet at the supermarkets in São Paulo, reduced from $12 \%$ in $1973 / 74$ to $7,4 \%$ in $1991 / 92$ and they attributed this reduction to the improvements in their supply system and to the management of the vegetables stock such as the utilization of refrigerator counters which increases the product shelf life.

The weight loss varies according to size and shape of the counter or exhibition surface. The larger roots of cultivar Nantes lost relatively less weight (11\%) compared with the smaller roots (13\%) in 3 days of storage (Diatchenko, 1971).

In revisions accomplished by Terrassioli Neto et al. (1998) it was noticed that the withered appearance, the loss at firmness, the sprouting and the occurrance of diseases are the main causes of beet postharvest losses during its storage and sale

So, this work had the objective of evaluating the sugar beet postharvest conservation under modified atmosphere and at environmental condictions.

\section{MATERIALS AND METHODS}

The experiment was conducted in the Laboratory of postharvest from Nucleous of Agrarian Science (NCA) at Universidade Federal do Mato Grosso do Sul (UFMS), in Dourados, MS.

The beets were washed and after drying at environmental temperature they were conditioned in isopor trays $(1,5 \times 7,0 \mathrm{~cm})$. The atmosphere modification was obtained by the coating of the trays, with a film of PVC, commercially wellknown as Rollopac.

The experiment was conducted at environmental temperature $\left(15-26{ }^{\circ} \mathrm{C}\right)$ using an entirely randomized design with $3 \times 2$ factorial scheme: 3 sizes (small, medium and large) and 2 packages ( PVC and without packing) with three replications of five beets.

At the beginning and in the end of the experiment, $\mathrm{pH}$ was evaluated and determined in $\mathrm{pH}$-meter Micronal mod. B 374, according to a technique established by AOAC (1990), the results were expressed in $\mathrm{pH}$ units; Titled Total Acidity (TTA) determined by the electrometer method. The percentage of citric acid was determined multiplying the volume of $\mathrm{NaOH} 0,1 \mathrm{~N} \times 10 \mathrm{ml}$ of sample $x$ citric acid factor $(0,06404)$; Total Soluble Solids (TSS) determined with a manual refrationmeter Shibuya optical Co. Ltda. , according to the AOAC methodology (1990) and the results expressed in ${ }^{\circ}$ Brix. The beet classification in relationship to the size was determined according to the strip: large above $130 \mathrm{~g}$, medium between 81 and $129 \mathrm{~g}$ and small below $80 \mathrm{~g}$.

\section{RESULTS AND DISCUSSION}

The medium values of beets weight loss are shown at table 1 .

It was noticed that the PVC packing reduced in eightfold to ninefold the weight loss, when compared to non-packed roots. Inside the packing, the small beets showed significantly larger weight loss than the large beets, while the media beets didn't differ from the others.

For the beets under controlled conditions, it was noticed that those beets with medium and small sizes presented weight losses significantly larger than the large ones.

Table 1 - Medium values of the weight loss (\%) from the small, medium and large beets stored for 14 days with and without packing one at $\left(15\right.$ to $\left.26^{\circ} \mathrm{C}\right)$. UFMS, Dourados - MS.

\begin{tabular}{lccc}
\hline \multicolumn{1}{c}{ Size } & \multicolumn{4}{c}{ Treatment } \\
& PVC & \multicolumn{3}{c}{ Control } \\
\hline $\mathrm{S}$ & $4,676 \mathrm{~A}$ b & $38,547 \mathrm{~A} \mathrm{a}$ \\
$\mathrm{M}$ & $4,160 \mathrm{AB} \mathrm{b}$ & $37,220 \mathrm{~A} \mathrm{a}$ \\
$\mathrm{L}$ & 3,883 & $\mathrm{~B} \mathrm{~b}$ & $33,407 \mathrm{~B} \mathrm{a}$ \\
\hline
\end{tabular}

Averages followed by the same small letter in the column with capital letter in the line are statistically equal by $\mathrm{F}$ and Tukey tests $(\mathrm{P}<0,05)$ respectively. 
After 14 days of storage, the controlled beets were considered not proper for commercialization due to their advanced stage of withering. Although the experiment had been finished when the controlled beets presented a medium weight loss of 55\% and those stored under modified atmosphere $8 \%$, they were maintained until 22 days and then, they presented a final weight loss of $15,82 \%$ (Fig. 1).

During the 22 days of storage the beets presented sprout signs, but they didn't present signs of withering. These results were in agreement with those found by Terrassioli Neto et al. (1998) who said that storing beets with 6 to $8 \mathrm{~mm}$ of diameter in different packing types for 18 days, they observed that at 12 days of storage, it had already happened sprout in the packed roots which were closed with polyethylene.

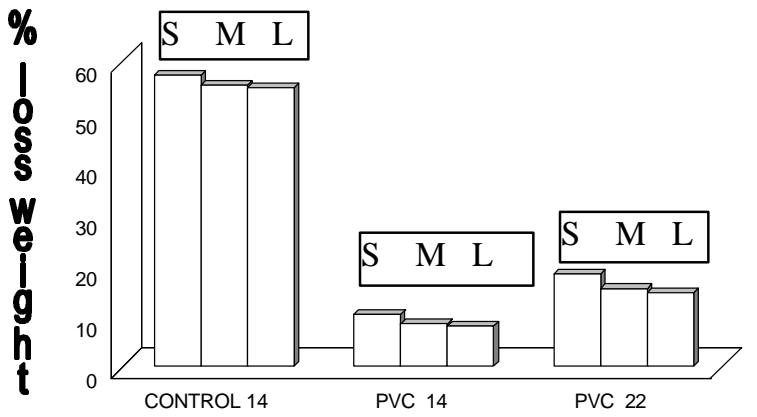

Figure 1 - Medium values of beets weight loss stored with and without packing after 14 days, and with packing after 22 days at the temperature of $15-26^{\circ} \mathrm{C}$.

During this period, they didn't observe withering symptoms in these roots lither packed with PVC or with perforated polyethylene sacks.

In this work, the weight loss observed in the nonpacked roots was higher than that one observed by Terrassioli Neto et al. (1998) after 12 days of storage $(21,03 \%)$, while the medium weight loss of the roots packed with PVC was at the same strip observed by them $(4,51 \%)$. In revisions accomplished by these authors it was observed that losses of fresh material above $15 \%$ made the beets useless for commercialization.

Avelar Filho (1989) stored arracacha at $24-32{ }^{\circ} \mathrm{C}$, and observed the weight loss, of 22,92 for small roots, 15,72 for medium ones and $13,29 \%$ for large ones during 8 days without packing. The roots stored under a modified atmosphere, presented losses of 0,$92 ; 0,84$ and $0,85 \%$, so they were 18 times smaller than the control.
The $\mathrm{pH}$, TSS and TTA contents are used as quality parameter in many fruits and vegetables. The content of organic acids usually decreases due to the breathing process and TSS mainly increases due to the starch hydrolysis in sugar total soluble . In table 2 it was observed the beets didn't present significant differences in $\mathrm{pH}$ contents $(6,19-6,30)$; TSS (10 - 13) and TTA $(10,80-1,047)$ during the experiment except TTA during the 22 days of storage, which was higher in the small beets. However, on the average, the $\mathrm{pH}$ was higher in large beets, which presented smaller TSS and TTA.

Table 2 - pH values, total soluble solids (TSS) and total titration acidity (TTA) of beets stored under a modified atmosphere during 22 days at temperature of $15-26^{\circ} \mathrm{C}$ (Dourados, MS).

\begin{tabular}{cccc}
\hline Size & \multicolumn{4}{c}{ Time } \\
& $\mathrm{T}_{0}$ & $\mathrm{~T}_{22}$ & Average \\
\hline \multicolumn{5}{c}{$\mathrm{pH}$} \\
$\mathrm{S}$ & 6,20 & 6,19 & $6,20 \mathrm{~B}$ \\
$\mathrm{M}$ & 6,20 & 6,23 & $6,21 \mathrm{~B}$ \\
$\mathrm{~L}$ & 6,30 & 6,30 & $6,30 \mathrm{~A}$ \\
\hline \multicolumn{5}{c}{$\mathrm{TSS}$} \\
$\mathrm{S}$ & 12,50 & 13,00 & $12,75 \mathrm{~A}$ \\
$\mathrm{M}$ & 11,50 & 13,00 & $12,25 \mathrm{AB}$ \\
$\mathrm{L}$ & 10,00 & 12,00 & $11,00 \mathrm{~B}$ \\
\hline \multicolumn{5}{c}{ TTA } \\
$\mathrm{S}$ & $0,82 \mathrm{~A}$ & $1,05 \mathrm{~A}$ & $0,99 \mathrm{~A}$ \\
$\mathrm{M}$ & $0,82 \mathrm{~A}$ & $0,82 \mathrm{~B}$ & $0,82 \mathrm{~B}$ \\
$\mathrm{~L}$ & $0,82 \mathrm{~A}$ & $0,80 \mathrm{~B}$ & $0,81 \mathrm{~B}$ \\
\hline
\end{tabular}

Averages followed by same capital letter in the column are statistically equal by Tukey test $(\mathrm{P}<0,05)$.

The small increase in TSS content observed at the end of the storage could happen due to the small loss of water causing a concentration of soluble solids. These results indicated that the modified atmosphere maintained the roots quality during the storage, although in the revisions of Chitarra and Chitarra (1990) it wasobserved that the beet presented few or no benefit with the usage of modified atmosphere.

\section{RESUMO}

Este trabalho teve como objetivo avaliar a conservação pós-colheita de beterrabas sob atmosfera modificada e à temperatura ambiente $\left(15-26{ }^{\circ} \mathrm{C}\right)$. O experimento foi conduzido em delineamento inteiramente casualizado em fatorial três tamanhos (pequeno, médio e grande) e duas embalagens (PVC e sem embalagem) em três repetições de três beterrabas. Foram avaliados no 
início e final do armazenamento o $\mathrm{pH}$, teores de Sólidos Solúveis Totais e Acidez Total Titulável, e durante o armazenamento a porcentagem de perda de peso. Observa-se que a embalagem reduziu de 8 a 9 vezes a perda de peso, sendo que as beterrabas pequenas apresentaram menor perda que as grandes. Aos 14 dias de armazenamento, as beterrabas sem embalagem apresentavam-se imprestáveis para comercialização devido ao estágio avançado de murcha, com perda média de peso de 55\%; as beterrabas embaladas com PVC permaneceram com boa aparência até os 22 dias de armazenamento com perda média de peso de $15,82 \%$. Os teores de pH, TSS e TTA não apresentaram diferença significativa nas beterrabas embaladas, exceto a TTA aos 22 dias, que foi maior nas beterrabas pequenas. Em média, o pH foi maior e a TTA e TSS menor nas beterrabas grandes.

\section{REFERENCES}

A.O A.C. (1992) Official methods as analysis of the association of official analytical chemistry. Washington, DC.

Apeland, J.; Bangerod, H. (1971)Factors affecting weight loss in carrots. Acta Horticulturae, 1, 92-97.

Araújo, M. L. ; Leal, N. R. ; Moura, L. L. S. ; Vasconcelos, H. De O. (1983) Influência de sistemas de cultivo na produção e no rendimento de betacianina em raízes de beterraba. Itaguaí. PesagroRio, (Pesogro- Rio. Comunicado Técnico, 13)

Avelar Filho, J. A. (1989) Estudo da conservação póscolheita da mandioquinha - salsa (Arracacia xanthorrhiza Brancrof) Viçosa. UFV, (Tese, MS).

Bleinroth, E. W.(1989) Colheita e armazenamento de frutas e hortaliças para processamento. Boletim ITAL, 6, $1-8$.

Cerreta, C. A. ; Dávalos, E. D. \& Milanez J. M. (1983) Avaliação de cultivares de beterraba açucareira. Florianópolis, EMPASC, (EMPASC. Pesquisa em andamento, 19).

Coursey, D. G.(1986) Post harvest losses in perishable foods of the developing wols. In: Lieberman, M. (ed). Pos harvest plysiology and crop preservation. New York, Pelnum Press, $485-511$.
Diatchenko, V.S. (1971) Some biological peculiarities and storage methods of carrots. Acta Horticulturae, 20, 80-91.

Fundação Educacional Padre Landell De Moura, FEPLAM,(1973) Manual de Olericultura, cultivo de horta. , editora FEPLAM.

Kader, A.A. (1992) Postharvest technology of horticultural crops. Oakland:University of California,296p.

Kader, A. A. ; Kasmire, R. F. ; Mitchell, F. G. ; Reid, M. S. ; Sommer, N. F. ; Thompson, J. F. (1985) Postharvest technology of horticultural crops California. Davis Cooperative Extension University of Califórnia. Division of Agriculture and Natural Resources, ( special publication, 3311).

Lopes, L. C. (1980) Anotações de fisiologia póscolheita de produtos hortícolas. Viçosa.

Moura, L. L. \& Siqueira, F. A. R. (1983). Conteúdo protéico e composição em aminoácidos de beterraba açucareira, Beta vulgaris l. Chenopodiaceae. Rio de Janeiro, Embrapa/ CTAA,.(EMBRAPA/ CTAA, Comunicado técnico, 5).

Pantastico, E. B. ; Chttaopadhyay, T. K. ; Subramanyam, H. (1975) Storage and commercial Storage operations. In: Pantastico, Er. B. ed. Postharvest physiology, handling and utilization of tropical and subtropical fruits and vegetables. Westport: AVI, cap.16.

Phan, C.T. (1974) Use of plastic films in the storage of carrots. Acta Horticulturae, 38, 345-350.

Scalon, S.P.Q.; Heredia, Z.N.A.; Vieira, M.C. (1998) Conservação pós-colheita de mandioquinha-salsa em atmosfera modificada. In: CONGRESSO BRASILEIRO DE OLERICULTURA, 38, Petrolina PE, Resumos.

Terrassioli Neto, J.; Ricardo, A .K.; Jacomino, A.P.; Scarpe $F^{0}$. J.A.; Iwata, A .Y.(1998) Conservação de raízes de beterraba 'Early Wonder'em diferentes tipos de embalagens. Horticultura Brasileira, 16, 7-10.

Tsunechiro, A. ; Ueno L. H. ; Pontarelli C. T. G. (1994) Avaliação econômica das perdas de hortaliças e frutas no mercado varejista da cidade de São Paulo, 1991/92. Agricultura em SãoPaulo, 41, 1 - 15.

Wills, R. H. H. ; Lee, T. H. ; Grahan, D. (1981) Postharvest .The avi Publishing Company Inc. Westport.

Received: November 23, 1998; Revised: February 02, 1999; Accepted: November 22, 1999. 